\section{Variability of aggressiveness and virulence of Erwinia carotovora subsp. carotovorum causing the soft rot on potato tubers in the western of Algeria}

\author{
M'hamed Benada, ${ }^{1,2}$ \\ Boualem Boumaaza, 2,3 \\ Sofiane Boudalia, ${ }^{2,3}$ Omar Khaladi, ${ }^{2}$ \\ Bettache Guessas ${ }^{1}$
}

${ }^{1}$ Laboratory of Applied Microbiology, Department of Biology, Faculty of Natural and Life Sciences, University

Oran 1, Ahmed Ben Bella; ${ }^{2}$ Department of Ecology and Environement,

University 8 May 1945, Guelma;

${ }^{3}$ Laboratory of Biology, Water and

Environement, University 8 May 1945 , Guelma, Algeria

\begin{abstract}
Soft rot symptoms were observed on potato plants in several potato cultivars in the western part of Algeria. A total of four strains of Erwinia are devided as follow: i) three strains of bacteria isolated from diseased tissues and soil, identified as Erwinia carotovora subsp carotovorum using conventional bacteriological and biochemical methods; and ii) one strain as Erwinia sp, not pathogens. In vitro tests, on tuber slices were set up to determine slices weight lost, which allows to find differences in cultivar susceptibility and isolate aggressiveness. Among the five cultivars, Laura was the most susceptible than the others tested cultivars. Moreover, it was found that MAI isolate was the most virulent than the other bacterial isolates.

The results of this study should allow an optimization of the potato storage, after considering the susceptibility of a given cultivar to soft rot development and the aggressiveness.
\end{abstract}

\section{Introduction}

In Algeria, potato (Solanum tuberosum L.) is the most important crop and is becoming an increasingly important source of food. However, production has been affected by the serious damages caused by the number of fungal and bacterial diseases. Erwinia carotovora subsp. carotovora is a gram-negative bacterium that causes soft rot disease of economically important crops, such as potatoes, tomato, broccoli and cucumbers. ${ }^{1-4}$ This pathogen is a widespread and economically important disease of potato, which causes soft rot of stem and tubers before and after harvest, and greatly reduces yields. ${ }^{2}$

Nowaday E carotovora is a problem in the eastern regions Algerian, due to the environmental conditions. Thus, temperature and water availability are two of the main impact on the development of this bacterial disease. ${ }^{5}$ The effect of these factors may result from structural and physiological changes in the plant, increased incidence and severity of diseases when $\mathrm{T}$ and $\mathrm{RH}$ were highest $\left(20^{\circ} \mathrm{C}\right.$ and $\left.100 \%\right) .^{5}$ The disease also has a negative impact on the storage potential of a crop, which constitutes the major source of primary inoculum in potato crops and a site where the pathogen can remain latent. The disease is related to the level of seed contamination by the bacterium under favorable conditions. Planting of seed tubers contaminated with Erwinia can result in reduced emergence, reduction in crop cover and rotting of tubers in the field, all of which can lead to significant yield losses. ${ }^{6}$ The bacteria enter plant tissue mainly in wounds. They spread via and multiply in the intercellular spaces of suberized or parenchymatous tissues. Plant cell walls are degraded and tissue is macerated by Pectolytic enzymes released from the bacteria. Macerated tissues are wet, cream to tan in color, with a soft, slightly granular consistency.

The taxonomy of soft rot bacteria of vegetables has been studied intensively in order to clarify their classification. ${ }^{7,8}$ Gardan et al. ${ }^{9}$ proposed that detection of pectolytic activity of Erwinia should be included in a separate genus, Pectobacterium. However, both classifications are still valid in the scientific literature. Three bacteria can cause soft rot and can be distincted by temperatures; Erwinia carotovora subsp. atroseptica with optimum temperature $20^{\circ} \mathrm{C}$ can infect potato plants and tubers, Erwinia carotovora subsp. carotovora and Erwinia chrysanthe$m i$ with a high temperature of infection 20 to $35^{\circ} \mathrm{C} .{ }^{10}$

The availability of genetic resistance to disease has permitted the production of many crops in areas. However, selection of genotypes is the only control unappropriated for many diseases, for which genetic resistance is the extreme importance in disease resistance and of disease control by means of host resistance. Over the last few years, genetic resistance of plant pathogens have been accepted as a key practice in sustainable agriculture and is one of the best methods to control bacterial pectolytic of
Correspondence: M'hamed Benada, Laboratory of Applied Microbiology (LMA), Department of Biology, Faculty of Natural and Life Sciences, University Oran 1, Ahmed Ben Bella; Department of Ecology and Environement, University 8 May 1945, Guelma, Algeria.

E-mail: mbenada@yahoo.fr

Keywords: Solanum tuberosum; Erwinia carotovora; soft rot; sensitivity; virulence; pathogenicity.

Acknowledgments: The authors also acknowledge the technical support provided by Mr. Gacemi A for statistical analysis.

Received for publication: 7 January 2018

Revision received: 20 March 2018.

Accepted for publication: 26 June 2018.

This work is licensed under a Creative Commons Attribution-NonCommercial 4.0 International License (CC BY-NC 4.0).

(C) Copyright M. Benada et al., 2018

Licensee PAGEPress srl, Italy

International Journal of Plant Biology 2018; 9:7568 doi:10.4081/pb.2018.7568

potato tubers. ${ }^{11}$ Several studies have demonstrated the ability of several genotypes of potato tubers to possess the source of resistance for all potato diseases. Resistance resources have been identified in most related wild species of potato.

This study aimed to isolate and identify the bacterium associated with recently occurred soft rot on potato in western of Algeria, for one hand to identify the sensitivity to soft rot caused by E. carotovora in a collection of five potato genotypes. On the other hand to assess the resistance of selected genotypes to four isolates varying in virulence, using in vitro test to determine slices weight lost. Four different bacteria of Erwinia on five varieties of potato have been studied. The bacteria have been selected because they are known of their aggressivity and strong resistance to the in vitro test.

\section{Materials and Methods}

\section{Isolation of bacteria}

Samples of potato plants showing symptoms of soft rot were collected in the harvest of potato heads in April and June of 2014. Isolation of the pathogen was carried out using fragments cut out with a sterile scalpel from the border area between apparently healthy tissue and diseased dark brown tissue. The samples were homoge- 
nized in a few drops of sterile distilled water using pestle and mortar. After a few minutes, a loopful of resulting homogenate was streaked on nutrient agar medium and incubated for 2-3 days at $27^{\circ} \mathrm{C}$.

After purification and different test of identification, the strains are stored in glycerol $30 \%$ at $-80^{\circ} \mathrm{C} .{ }^{12}$

\section{Biochemical tests}

The bacterial strains that were confirmed as Erwinia carotovora by several Biochemical tests. Five biochemical tests were carried out prior to characterization of bacteria which were oxidase, catalase, Gram staining, arginine dihydrolase and facultative anaerobic.

\section{Gram staining}

Transfer a loopful of the liquid culture to the surface of a clean glass slide. A loopful of tap water on a slide. Allow the film to air dry. Fix the dried film by passing it briefly through the Bunsen flame. Flood the slide with crystal violet solution for up to one minute. Wash off briefly with tap water (not over 5 seconds). Flood slide with Gram's Iodine solution, and allow acting (as a mordant) for about one minute. Wash off with tap water. Flood slide with $95 \%$ alcohol for 10 seconds and wash off with tap water. Flood slide with safranin solution and allow countering stain for 30 seconds. Wash off with tap water. Drain and blot dry with bibulous paper.

\section{Oxidase test}

Place a piece of filter paper in Petri dish and add 3 drops of $1 \%$ solution of tetramethyl-p-phenylene diamine dihydrochloride. Using a sterile glass rod, remove a colony of test organisms from a culture plate and smear it on the filter paper.

\section{Catalase test}

A clean microscope slide was taken. 2-3 $\mathrm{mL}$ of hydrogen peroxide was placed at the centre of the slide. Take a colony of test organism with sterile wooden and immerse it into hydrogen peroxide solution. Observe for generation of bubbles. This indicates oxygen production.

\section{Arginine dihydrolase test}

The medium of Arginine dihydrolase is sterilized by autoclaving at $120^{\circ} \mathrm{C}$ for 20 min, distributed in $2 \mathrm{~mL}$ in test tubes, and stored at $4^{\circ} \mathrm{C}$. Both tubes were inoculated by stabbing the media one half way to the bottom. A control medium without L-arginine was also used. The medium is inoculated by stab and the surface then covered with a $5 \mathrm{~mm}$ of sterile liquid paraffin, tightly capped, and incubated at $35^{\circ} \mathrm{C}$ for 7 days. The tubes were observed on days 1, 2, 5, and 7 for positive or negative results. A positive test was indicated by a deep pink to red color, whereas a negative test was remained unchanged or turn yellow.

\section{Pathogenicity test}

Pathogenicity of the isolated strains was tested by inoculation in tobacco plant (Nicotiana tabacum), to know hypersensitivity with the method of Shaad et al., ${ }^{13}$ head tissue fragments. The inoculum was prepared from a $24 \mathrm{~h}$ old culture of tested strains grown on nutrient agar (NA) and suspended in sterile distilled water. Concentration was adjusted to approx. $10^{9}$ $\mathrm{CFU} / \mathrm{mL}$ of cell density were prepared for verifying their ability to cause soft rot disease. For each isolate, $10 \mu \mathrm{L}$ of the abovementioned suspension was inoculated in a petiole by injection. Sterile distilled water was used as a negative control, while $P$. carotovorum subsp. carotovorum was used as a positive control. The inoculated plants were kept in a glasshouse (temperature range: $25-30^{\circ} \mathrm{C}$, photoperiod: $12 \mathrm{~h}$ ). Symptoms were examined daily for 3 days. A pathogenicity test on Leaf area (five to six leaves) was performed as described by Wright. ${ }^{14}$ After observation of disease symptoms, which were soft rot-like. Necrosis (the tissues dry up and take a light brown color to beige) of the infiltrated area after 24,48 and $72 \mathrm{~h}$ was considered a positive reaction. A reaction positive shows the pathogenicity of the bacterium.

\section{Selection of potato genotypes resist- ant to soft rot}

Potato cultivars (Spunta, Kondor, Laura, Margarita and Desire are commercially variety in Algeria) were selected free of wounds and homogeneous in size. They were stored at $4^{\circ} \mathrm{C}$ until use. Tubers were surface disinfected by soaking in $70 \%$ ethanol, then washed with sterile distilled water. The bacteria suspension was prepared as described above.

\section{Aggressiveness and virulence test}

A total of 75 slices with about $5 \mathrm{~mm}$ thick were used in this study. The experimental protocol used in this work has been inspired of Haynes et al. ${ }^{15,16}$ Each slice was cut in the center of the tuber and then placed in a Petri box containing $1 \mathrm{~mL}$ of sterile water. A sterile filter paper of $1 \mathrm{~cm}^{2}$ is placed at the wafer center. The initial weight is assessed, and then $100 \mu \mathrm{L}$ of bacterial suspension $\left(10^{8} \mathrm{UFC} / \mathrm{mL}\right)$ is deposed on filter paper. For the control group, Phosphate Buffered Saline (PBS) is applied in place of the bacterial suspension. Petri box was wrapped with parafilm to limit gas exchange and incubated at $28^{\circ} \mathrm{C}$ for $48 \mathrm{~h}$. For this experiment, four strains (SOL, SA, MAI, and JELLY) that exhibited various degrees of virulence were selected (Figure 1).

\section{Statistical analysis}

The results were expressed in the form of the mean \pm SEM (standard error mean). All results were analyzed based on a comparison of the mean and an analysis of variance (ANOVA), followed by the test of Tukey when the conditions of normality and homogeneity of the variances are observed. ANOVAs were performed by considering the effect of strain, variety as well as the interaction strain $x$ variety. Significance was considered at $\mathrm{P}<0.05$ using MiniTab software [Minitab, Ltd, United Kingdom (Version 16)].

\section{Results \\ Morphological and biochemical characteristics}

The isolated bacteria were identified as Erwinia carotovora sp. carotovora by standard bacteriological techniques; disease symptoms, pathogenicity tests, colony morphology (Figure 2) and biochemical tests. Based on our morphological analysis of the bacterial colonies, the colonies appeared to be shiny and creamy white after $48 \mathrm{~h}$ incubation at $27^{\circ} \mathrm{C}$. According of these biochemical tests, bacteria obtained from purified colonies, were Gram-negative, oxidase negative, arginine dihydrolase negative, catalase positive, and facultative anaerobic, fermentative in hugh leifson and no fluoresces in UV confirmed our bacterial isolates as Erwinia carotovora sp. Carotovora.

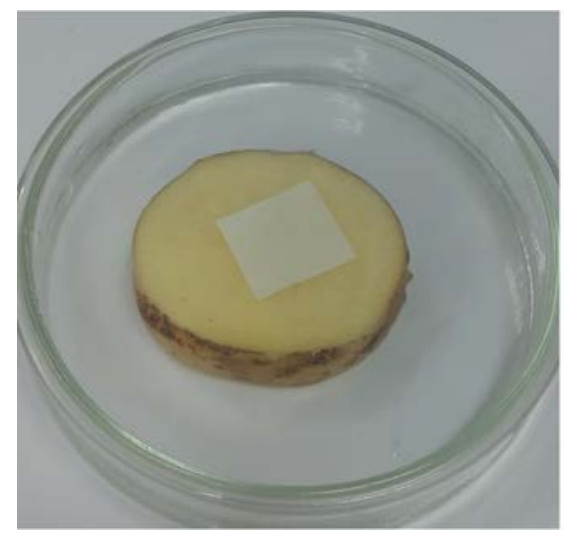

Figure 1. Slices of potato infected with SA strain. 


\section{Pathogenicity test}

In leaves inoculation test, four bacterial isolates were used. Results of the pathogenicity test showed that within three days after inoculation, yellow halo on the leaves was observed on inoculated tobacco plants (Figure 3). Control plants inoculated with water remained healthy. The strains Sol, SA and MAI are positive result (Presence of necrosis), which reflects that these strains are pathogenic, so have the capacity to cause the disease when they are contacted with host plant in favorable condition. Among these, one isolate JELLY gave a negative result; it is not pathogen strain (Table 1).

\section{Weight loss}

After $48 \mathrm{~h}$ and after removing the decay from the slices, a second weighing is carried out. The results showed wide variation in susceptibility of potato cultivars to the bacterial inoculation.

Five cultivars had high disease-symptom severity scores when assessed for soft rot resistance when tested with method Haynes et al. and Czajkowski et al. ${ }^{15,16}$

Jelly strain is in the last with the same results as negative control, which tends to 0 .

The virulence results of Erwinia carotovora subsp. carotovora in different varieties of potatoes, we saw there is a significant difference between strains in same varieties and between different varieties; variations among the strains in virulence and sensitivity were significant $(\mathrm{P}<0.05)$. The strain MAI is the most virulent than other strains in Spunta and Kondor varieties. MAI strains consistently macerated potato tuber tissue more rapidly than strains of SOL and SA in Spunta and Kondor varieties for three replications of the experiment with $41.93 \%, 36.43 \%$ and $22.09 \%$ successively of weight loss in Kondor and $55.23 \%, 29.53$ and $31.15 \%$ in Spunta (Figure 4). In virulence, the three strains SOL, SA and MAI induced a susceptible reaction on Desire varieties, while the strain Jelly has the same result than negative control, which tends to 0 .

As results have shown, the potato Desire variety was less damaged by an artificial infection of E. carotovora sp. carotovora than other varieties. Therefore, this variety is more resistant to the disease. Strains SOL and SA have same degrees of virulent in Spunta and SOL was more virulent and aggressive than SA in Kondor. In Laura and Margarita varieties, the strain SOL is more aggressive than MAI, who is more aggressive than SA with $57.28 \%$ of weight loss in Laura and $32.09 \%$ in margarita, and SA is more aggressive than Jelly with $\mathrm{P}<0.05$. If we compare the results between different varieties, we see that the Desire varieties is the most resistant than other varieties (Kondor, Margarita, Spunta, and Laura) with a loss that is at a maximum with the strain MAI, which is $20.21 \%$, and the Laura varieties is the most sensitive, with maximum of loss which is with $55.23 \%$ in strain MAI.

\section{Discussion and Conclusions}

Bacterial soft rot is one of the most important factors, which cause crop losses in tubers and stem both in the field and greatly reduce yield during storage. Over the last years, these bacteria cause serious damage and are involved in soft rot diseases of several cultivars in Algeria. ${ }^{17}$ Due to the inefficiency of chemical control, development of alternative control is great importance. The resistant cultivar is one of the best methods to control bacterial pectolytic of potato tubers. ${ }^{11}$ The comparison of virulence and aggressiveness of four strains Erwinia carotovora subsp. carotovorum was studied by using 5 genotypes of potato tubers arising the western of Algeria.

The present results suggest that four isolates were pathogenic to eggplant with different degrees of aggressive and caused varying degrees of soft rot. As observed by several authors, when a critical number of Pectobacterium spp. is reached at the infection site, Ecc produces an assortment of degradative enzymes including pectate lyase isozymes (Pels), polygalacturonase (Peh), cellulase $(\mathrm{Cel})$, protease (Prt) and pectin lyase $(\mathrm{Pnl}) .{ }^{6,18-20}$ This production is controlled by a quorum-sensing process that relies upon the production of $\mathrm{N}$-acylho-
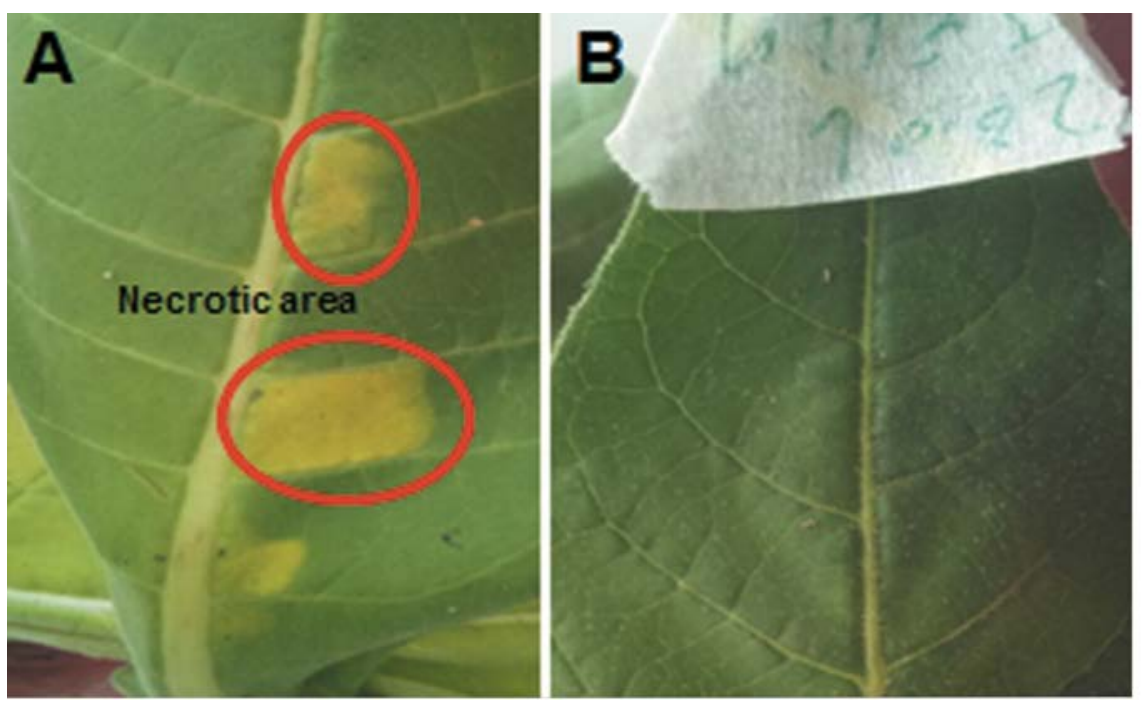

Figure 3. Yellow symptom was appeared on tobacco leaves after inoculation with $\mathrm{Pa}$ isolate; A) Positive result; B) Negative result.
Table 1. Results of pathogenicity test.

Negative control

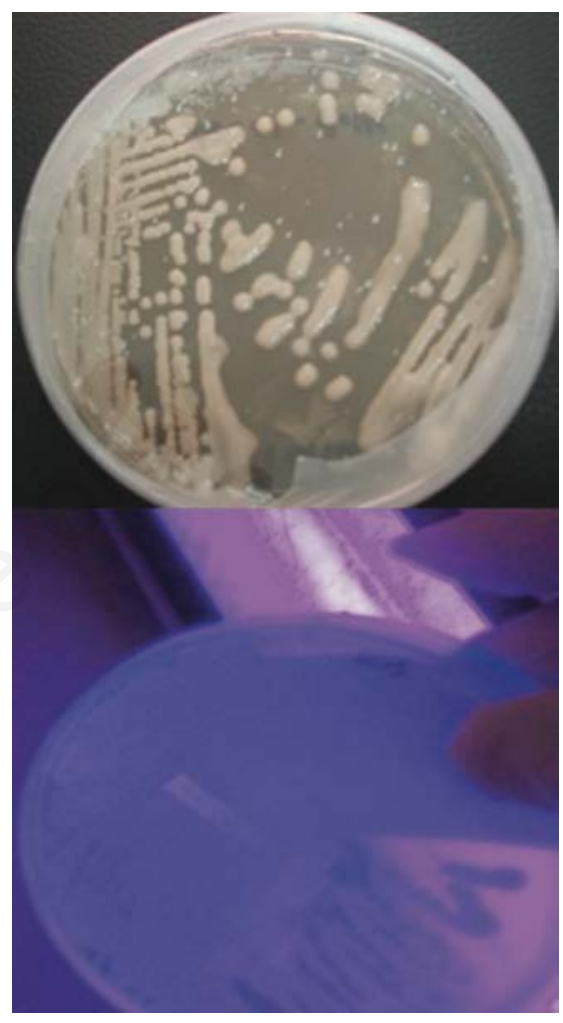

Figure 2. A) Erwinia carotovora in LPGA medium. B) Erwinia carotovora in King B medium in ultra violet radiation.

$\begin{array}{lc}\text { Strain } & \text { Result } \\ \text { MAI } & + \\ \text { SOL } & + \\ \text { SA } & + \\ \text { JELLY } & -\end{array}$


moserine lactones (HSL). ${ }^{12,21}$

In pathogenicity tests, variation in host resistance (potato) and in the ability of pathogens (Erwinia carotovora subsp. carotovorum) to infect and aggressiveness are essential underlying factors influencing soft rot disease. In previous studies, it is interesting to note that, some strains were isolated from the same tubers and have not proved the same capacity to produce the soft rot disease, such as the strains JELLY. These results were in line with those of Smith et al., ${ }^{22}$ showed that significant difference $(\mathrm{P} \leq 0.05)$ were found among the strains for aggressiveness on tuber but the relative aggressiveness in one host was not always associated with aggressiveness or pathogenicity in another host.

Because of artificial inoculation, four isolates were chosen, three isolates (SOL, $\mathrm{SA}$, and MAI) were highly pathogenic, while one isolate (JELLY) were no pathogenic. However, in our tests, the pathogenicity of certain isolates differed between cultivars, and varied among isolates that were isolated at the same time. Among potatoes variety, Desire presented the lowest mean of the weight loss showing the effect of this variety of resistance to soft rot. In fact, the ability to macerate potato tuber tissues at $27^{\circ} \mathrm{C}$ was lower for Desire, than for other varieties. This variety is grown in most regions of western Algerian and our results have shown that this pathogen is less widespread in these areas. The resistance of tuber tissue of cultivars Desiree to soft rot caused by PCA isolates could be related to the presence of phenolics compounds Wegener and Jansen, ${ }^{23}$ in coloured potato. Our results observed in agreement with the conclusions of several authors. ${ }^{24-26}$

In the present research, the inability of
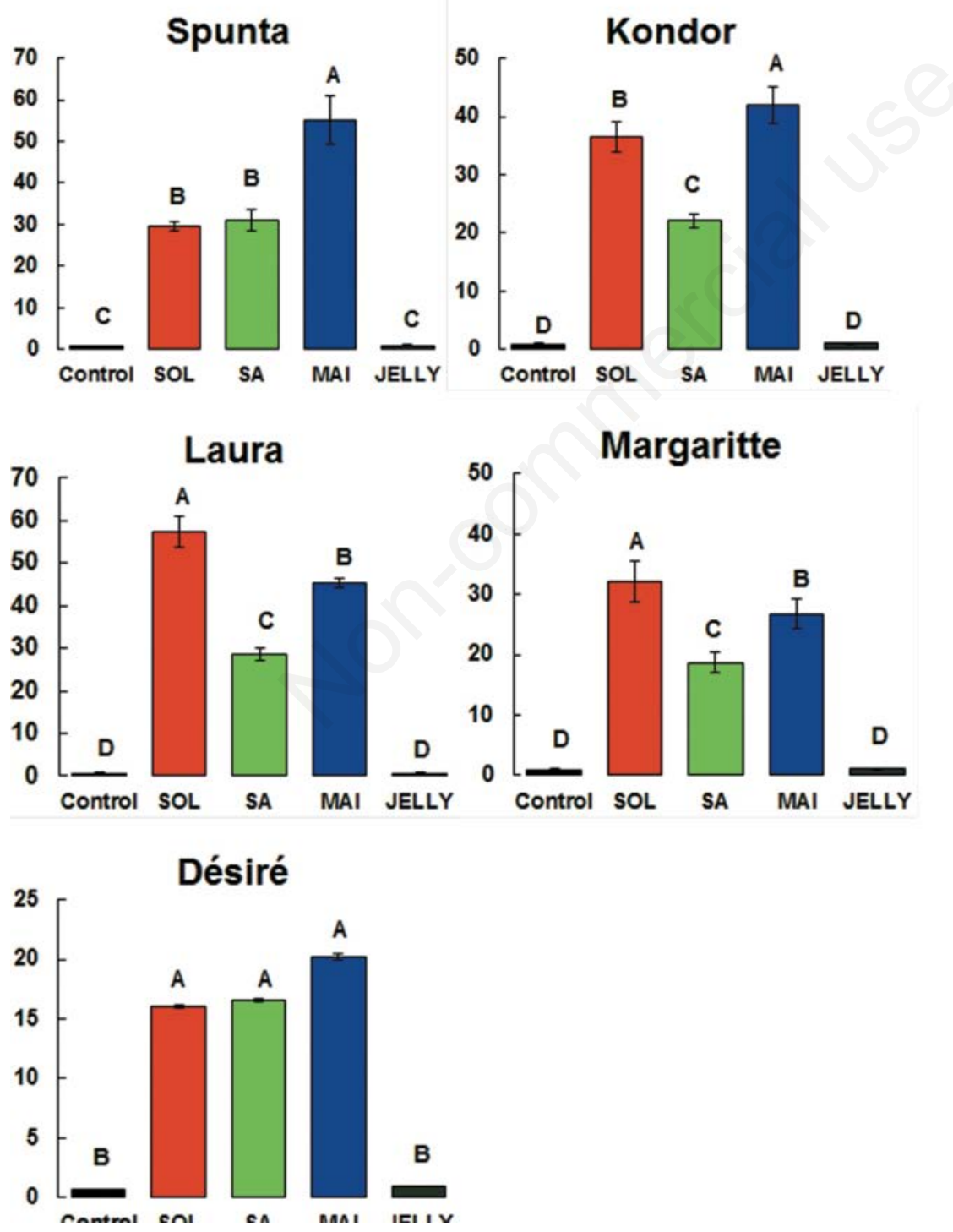

some strains (JELLY) to induce disease can be explained by the absence of enzyme production, particularly pectate lyase (PL). Maher and Kelman ${ }^{27}$ show that inability of the bacteria to degrade the lignified in tuber tissue is more related to the toxic substances, such as phenolics and phytoalexins could inhibit pectolytic enzymes of Erwinias.

In addition, the genotypes Kandor, Margarita, Desire, Spunta, and Laura have been determined as the most resistant to strains JELLY, which corresponds as potential sources of soft rot resistance; highlighting the need for continuing studies to identify sources of non- pathogenicity.

In conclusion, the results presented here show that Pcc strains can induce disease symptoms on potato and other vegetables. The resistant and sensibility of variety against soft rot caused by Erwinia carotovora subsp. carotovora, remains one of the means of fighting this disease, with using the resistant varieties who is the subject of our study. Among varieties used in Algeria, five of them were tested; which are Spunta, Kondor, Laura, Margarita. The Desire variety is the most resistant against soft rot disease; also, we think that we must use this variety in potato growing in Algeria.

\section{References}

1. Akbar A, Ahmad M, Azra N, et al. Characterization of the causal organism of soft rot of tomatoes and other vegetables and evaluation of its most aggressive isolates. Am J Plant Sci 2015;6:511-7.

2. Doolotkeldieva T, Bobusheva S, Suleymankisi A. Biological control of erwinia carotovora ssp. carotovora by streptomyces species. Adv Microbiol 2016;6:104-14.

3. Gašić K, Gavrilović V, Dolovac N, et al. Pectobacterium carotovorum subsp. carotovorum - the causal agent of broccoli soft rot in Serbia. Pest Phytomed (Belgrade) 2014;29:249-55.

4. Onkendi EM, Ramesh AM, Kwenda S, et al. Draft genome sequence of a virulent Pectobacterium carotovorum subsp. brasiliense isolate causing soft rot of cucumber. Genome Announc 2016;4:e01530-15.

5. Moh AA, Massart S, Jijakli MH, Lepoivre P. Models to predict the combined effects of temperature and relative humidity on Pectobacterium atrosepticum and Pectobacterium carotovorum subsp. carotovorum population density and soft rot disease development at the surface of wounded potato

Figure 4. Aggressiveness of strains E. carotovora, measured as a weight loss of tubers (\%). 
tubers. J Plant Pathol 2012;94:181-91.

6. Latour X, Faure D, Diallo S, et al. Lutte contre les maladies bactériennes de la pomme de terre dues aux Pectobacterium spp. (Erwinia carotovora). Cahiers Agric 2008;17:355-60.

7. Hauben L, Moore E, Vauterin L, et al. Phylogenetic position of phytopathogens within the Entrobacteriaceae. Syst Applied Microbial 1998;21:384-97.

8. Avrova AO, Hyman LH, Toth RL, Toth IK. Application of amplified fragment length polymorphism fingerprinting for taxonomy and identification of the soft rot bacteria Erwinia carotovora and Erwinia chrysanthemi. Appl Environ Microbiol 2002;68:1499-508.

9. Gardan L, Gouy C, Christen R, Samson R. Elevation of three subspecies of Pectobacterium carotovorum to species level: Pectobacterium atrosepticum sp. nov., Pectobacterium betavasculorum sp. nov. and Pectobacterium wasabiae sp.nov. Int $J$ Syst Bacteriol 2003;53:381-91.

10. Costa AB, Eloy M, Cruz L, et al. () Studies on pectolytic Erwinia spp. in Portugal reveal unusual strains of E. carotovora subsp. atroseptica. J Plant Pathol 2006;88:161-9.

11. Wright PJ, Crowhurst RN, Anderson JAD, Dale JR. Evaluation of potato cultivars and breeding lines for susceptibility to tuber soft rot induced by Erwinia carotovora subsp. atroseptica. N Zeal J Crop Hortic Sci 1991;19:187-90.

12. Toth IK, Van Der Wolf JM, Saddler G. Dickeya species: an emerging problem for potato production in Europe. Plant
Pathol 2011;60:385-99.

13. Shaad NW, Jones JB, Chun W. Laboratory guide for identification of plant pathogenic Bacteria. APS Press. Third edition. St Paul, Minnesota (US); 2001.

14. Wright PJ. A soft rot of calla (Zantedeschia spp.) caused by Erwinia carotovora subspecies carotovora. N Zeal J Crop Hort Sci 1998;26:331-4.

15. Haynes KG, Potts MJE, Goth RW. Evaluation of the reliability of determining soft rot resistance in potatoes by the tuber slice method. Am Potato J 1997;74:265-75.

16. Czajkowski R, de Boer WJ, van Veen JA, van der Wolf JM. Studies on the interaction between the biocontrol agent, Serratia plymuthica A30, and blackleg-causing Dickeya sp. (biovar 3) in potato (Solanum tuberosum). Plant Pathol 2012;61:677-88.

17. Yahiaoui-Zaidi R, Ladjouzi M, Benallaoua S. Pathogenic variability within biochemical groups of Pectobacterium carotovorum isolated in Algeria from seed potato tubers. Int J Biotechnol Mol Biol Res 2010;1:001009.

18. Barras F, Van Gijsegem F, Chatterjee A. Extracellular enzymes and pathogenesis of soft-rot Erwinia. Annu Rev Phytopathol 1994;32:201-34.

19. Maë A, Montesano M, Koiv V, Palva ET. Transgenic plants producing the bacterial pheromone $\mathrm{N}$-acylhomoserine lactone exhibit enhanced resistance to the bacterial phytopathogen Erwinia carotovora. Mol Plant-Microbe Interact 2001;14:1035-42.
20. Pérombelon MCM. Potato diseases caused by soft rot Erwinias: an overview of pathogenesis. Plant Pathol 2002;51:1-12.

21. Cirou A, Uroz S, Chapelle E, et al. Quorum sensing as a target for novel biocontrol strategies directed at Pectobacterium. Plant Pathol 2010 [Epub ahead of print].

22. Smith C, Bartz JA. Variation in the Pathogenicity and Aggressiveness of Strains of Erwinia carotovora Subsp. carotovora Isolated from Different Hosts. Plant Dis 1990;74:505-9.

23. Wegener CB, Jansen G. Potato Res Soft-rot resistance of coloured potato cultivars (Solanum tuberosum L.): the role of anthocyanins. Potato Res V 2007;50:31-44.

24. Ma B, Hibbing ME, Kim HS, et al. Host range and molecular phylogenies of the soft rot enterobacterial genera Pectobacterium and Dickeya. Phytopathology 2007;97:1150-63.

25. Seo ST, Furuya N, Lim CK, et al. Phenotypic and genetic diversity of Erwinia carotovora ssp. carotovora strains from Asia. J Phytopathol 2002;150:120-7.

26. El-Hendawy HH, Osman ME, Ramadan HA. Pectic enzymes produced in vitro and in vivo by Erwinia spp. isolated from carrot and pepper in Egypt. J Phytopathol 2002;150:431-8.

27. Maher EA, Kelman A. Influence of wounding and time in storage on susceptibility of Russet Burbank potatoes to Erwinia carotovora (EC) (abstract). Phytopathology 1984;74:880. 